\title{
Effects of Sand Composition on the Mechanical Properties of CA Mortar
}

\author{
Xiao-hui Zeng ${ }^{1,2}$, Hua Yan ${ }^{1}$, Fulin $\mathrm{Qu}^{2}$, Shun-hao \\ Wang ${ }^{2}$, Lilin Fu ${ }^{1}$, Kai Yang ${ }^{2}$ \\ ${ }^{1 .}$ Institute of Science and Technology, China Railway \\ Eryuan Engineering Group Co. Ltd., Chengdu 610031,
}

\begin{abstract}
In this paper, different rocks like marble, calcite, basalt, granite and quartz were used to produce the sand of CA mortar. Results showed that the type of sand had notable effects on the mechanical properties of CA mortar. For the calcium carbonate composition rocks like marble and calcite, when use the anion emulsified asphalt, the compressive strength and water resistance of CA mortar were higher than those of used the cation emulsified asphalt. But for the silica composition rocks like basalt, granite and quartz, the rule had reversed. Those may have the relationship with the charge type of the sand. Results also showed that for both of the anion and cation emulsified asphalt, when used the marble based sand, the compressive strength were very low. This paper may have some significance for the selection of the emulsified asphalt and sand of CA mortar.
\end{abstract}

Keywords-CA mortar; emulsified asphalt; charge type; sand; compressive strength

CA mortar is an organic-inorganic composite material used between the slab and concrete base of the slab track to level the track system, control and absorb the vibration. It's a key component of slab track system [1-5]. The main raw materials of CA mortar are emulsified asphalt, cement, sand, water and other additives. CA mortar has the characteristics of multiphase and organic-inorganic composite. The CA mortar applied to CRTS I slab track adopts cationic emulsified asphalt, but the CA mortar used in CRTS II slab track adopts anionic emulsified asphalt. The level of cement mainly is P.O42.5 or over P. II 42.5. The sand mainly is the river sand or artificial sand $[6,7]$.

There is no research about different types of sand have influence on the properties of CA mortar. The researches on the interaction of aggregate and asphalt are focused on the mixed materials of asphalt [8-12]. The researches on mixed materials of asphalt showed that carboxylic acid, aliphatic acid in the asphalt will have alkali aggregate surface reaction(some people believe it's the charge attraction related to molecular polarity) with calcium(like lime rock) that can produce high strength chemical bond $[8,9]$. But carboxylic acid always combined with alkali metal ions, and water can has a corrosion damage on it easily[10]. For silicic acid aggregates (like sandstone, granite, quartzite, river sand), the groups of $-\mathrm{SiOH}$ on the surface can just have reactions with the acidic materials in

\author{
China; \\ 2. School of Civil Engineering, Southwest of Jiaotong \\ University, Chengdu 610031, China;
}

asphalt and produce the hydrogen bond with low strength which can easily destructed by water[11, 12].

The harden CA mortar is mainly contented with unhydrated cement, cement hydration (most of them are $\mathrm{C}-\mathrm{S}-\mathrm{H}$ gel, $\mathrm{Ca}(\mathrm{OH})_{2}$, asphalt, sand, etc.). Unlike the low acid environment of the mixed materials of asphalt, $\mathrm{CA}$ mortar shows strong alkaline, the $\mathrm{pH}$ value could be higher than 13[13]. In that strong alkaline environment, effects of the interface between asphalt and sand will change. In additions, the asphalt applied to CA mortar could be cationic emulsified asphalt and anionic emulsified asphalt, the different types of charge have great influence on combining force. So it is very significant to research how different types of sand and charge of emulsified asphalt influence the mechanical properties of CA mortar.

\section{TESTS AND MATERIALS}

\section{A. Sand}

In this paper, we choose marble, calcite, basalt, granite, quartz as the raw materials of sand, and break the rock and classify them. We assort different sand that with different sizes to obtain the gradation we need. The gradation as follows:

TABLE1. GRAIN COMPOSITION OF THE SAND OF CA MORTAR

\begin{tabular}{llll}
\hline & Mesh size $(\mathrm{mm})$ & Passing rate\% & Quoted standard \\
Gradation & 1.18 & 100 & \\
& 0.6 & 92 & JGJ52-2006 \\
& 0.3 & 41 & \\
0.15 & 13 & \\
\hline
\end{tabular}

\section{B. Cement}

In this test, we chose P.O 42.5RPortland cement. The chemical and mineral compositions of this cement are seen in table 2 , physical properties are in table 3.

TABLE2. CHEMICAL AND MINERAL COMPOSITION OF CEMENT (\%)

\begin{tabular}{|c|c|c|c|c|c|c|c|c|c|c|c|c|}
\hline $\begin{array}{l}\text { comp } \\
\text { on }\end{array}$ & $\begin{array}{l}\mathrm{Si} \\
\mathrm{O}_{2} \\
\end{array}$ & $\begin{array}{l}\mathrm{Ca} \\
\mathrm{O} \\
\end{array}$ & $\begin{array}{l}\mathrm{Al}_{2} \\
\mathrm{O}_{3} \\
\end{array}$ & $\begin{array}{l}\mathrm{Fe}_{2} \\
\mathrm{O}_{3} \\
\end{array}$ & $\begin{array}{l}\mathrm{Mg} \\
\mathrm{O}\end{array}$ & $\begin{array}{l}\mathrm{SO} \\
3\end{array}$ & $\begin{array}{l}\mathrm{Na}_{2} \mathrm{O} \\
\text { eq }\end{array}$ & $\begin{array}{l}\text { f-Ca } \\
\mathrm{O}\end{array}$ & $\begin{array}{l}\mathrm{C}_{3} \\
\mathrm{~S} \\
\end{array}$ & $\begin{array}{l}\mathrm{C}_{2} \\
\mathrm{~S} \\
\end{array}$ & $\begin{array}{l}\mathrm{C}_{3} \\
\mathrm{~A}\end{array}$ & $\begin{array}{l}\mathrm{C}_{4} \mathrm{~A} \\
\mathrm{~F} \\
\end{array}$ \\
\hline cont & $\begin{array}{l}21 . \\
9\end{array}$ & $\begin{array}{l}65 . \\
9 \\
\end{array}$ & 4.6 & 2.7 & 1.8 & 1.8 & 0.6 & 1.0 & $\begin{array}{l}60 . \\
2 \\
\end{array}$ & $\begin{array}{l}17 . \\
3 \\
\end{array}$ & 7.6 & 8.5 \\
\hline
\end{tabular}


TABLE 3 PHYSICAL PROPERTIES OF CEMENT

\begin{tabular}{|c|c|c|c|c|c|c|}
\hline \multirow{2}{*}{$\begin{array}{l}\text { Specific } \\
\text { surface } \\
\text { area }\left(\mathrm{m}^{2} \cdot \mathrm{kg}^{-1}\right. \\
\text { ) }\end{array}$} & \multirow[t]{2}{*}{$\begin{array}{l}\text { Standard } \\
\text { consistency }(\% \\
)\end{array}$} & \multirow[t]{2}{*}{ Stability } & \multicolumn{2}{|c|}{$\begin{array}{l}\text { Rupture } \\
\text { strength(MPa }\end{array}$} & \multicolumn{2}{|c|}{$\begin{array}{l}\text { Compressive } \\
\text { strength(MPa } \\
\text { ) }\end{array}$} \\
\hline & & & $3 \mathrm{~d}$ & $28 \mathrm{~d}$ & $3 d$ & $28 \mathrm{~d}$ \\
\hline 342 & 27.5 & $\begin{array}{l}\text { qualifie } \\
\mathrm{d}\end{array}$ & 5.1 & 8.3 & 24.2 & 50.1 \\
\hline
\end{tabular}

\section{Expansive agent}

In this test, we used UEA expansive agent. It's made from calcium sulphoaluminate cement clinker, alum stone and gypsum. Calcium sulphoaluminate cement clinker is consisted with $\mathrm{C}_{4} \mathrm{~A}_{3} \mathrm{~S}$, free gypsum, lime, and few $\beta-\mathrm{C}_{2} \mathrm{~S}$. The physical and chemical properties are seen in table 4

TABLE 4 PHYSICAL AND CHEMICAL PROPERTIES OF U EXPANDING AGENT

\begin{tabular}{|c|c|c|c|c|c|c|c|c|c|}
\hline \multirow{2}{*}{$\begin{array}{l}\text { Speci } \\
\text { fic } \\
\text { surfa } \\
\text { ce } \\
\text { area } \\
\left(\mathrm{cm}^{2} /\right. \\
\mathrm{g})\end{array}$} & \multirow[b]{2}{*}{$\begin{array}{l}\text { Dens } \\
\text { ity }\end{array}$} & \multicolumn{8}{|c|}{ Chemical composition $/ \%$} \\
\hline & & $\begin{array}{l}\mathrm{Si} \\
\mathrm{O}_{2}\end{array}$ & $\begin{array}{l}\mathrm{Fe}_{2} \\
\mathrm{O}_{3}\end{array}$ & $\begin{array}{l}\mathrm{Ti} \\
\mathrm{O}_{2}\end{array}$ & $\begin{array}{l}\mathrm{Al}_{2} \\
\mathrm{O}_{3}\end{array}$ & $\begin{array}{l}\mathrm{Ca} \\
\mathrm{O}\end{array}$ & $\begin{array}{l}\mathrm{Mg} \\
\mathrm{O}\end{array}$ & $\mathrm{SO}_{3}$ & $\begin{array}{l}\text { Lo } \\
\text { ss }\end{array}$ \\
\hline 3180 & 2.88 & $\begin{array}{l}16 . \\
2\end{array}$ & $\begin{array}{l}0.9 \\
5\end{array}$ & $\begin{array}{l}0.8 \\
5\end{array}$ & $\begin{array}{l}13 . \\
89\end{array}$ & $\begin{array}{l}36 . \\
12\end{array}$ & $\begin{array}{l}2.9 \\
5\end{array}$ & $\begin{array}{l}24 . \\
25\end{array}$ & $\begin{array}{l}1.4 \\
5\end{array}$ \\
\hline
\end{tabular}

\section{Emulsified asphalt}

Asphalt particles dispersed in water because of emulsifier. Emulsifier molecules are absorbed in the surface of asphalt particles then the particles taking charge. According to the types of emulsifier, we can sort them to cationic, anionic and nonionic. The charge of asphalt and the surface properties have the influence on the bonding strength of asphalt with cement and sand. Furthermore, it will influence the strength and the ability of anti water damage. To research how the charge influence the water resistance of CA mortar, in this paper, we choose cationic and anionic emulsified asphalt as raw material of CA mortar. The properties are seen table 5 and table 6 .

TABLE5. MAIN PROPERTIES OF CATION EMULSIFIED ASPHALT

\begin{tabular}{|c|c|c|c|c|c|}
\hline $\begin{array}{l}\text { Serial } \\
\text { numb } \\
\text { er }\end{array}$ & \multicolumn{2}{|c|}{ Project } & Unit & $\begin{array}{l}\text { Test } \\
\text { results }\end{array}$ & $\begin{array}{l}\text { Test } \\
\text { metho } \\
\text { d }\end{array}$ \\
\hline \multirow[t]{2}{*}{1} & \multirow{2}{*}{\multicolumn{2}{|c|}{ appearance }} & & $\begin{array}{l}\text { Light } \\
\text { brown } \\
\text { liquid, } \\
\text { uniformit }\end{array}$ & $\mathrm{IC} / \mathrm{T}$ \\
\hline & & & & $\begin{array}{l}\text { y, no } \\
\text { mechanic } \\
\text { al } \\
\text { impuritie } \\
\mathrm{s}\end{array}$ & 797 \\
\hline 2 & Pol & rity of particles & & Positive & \multirow{6}{*}{$\begin{array}{l}\text { JTJ } \\
052- \\
2000\end{array}$} \\
\hline 3 & Eng & ler viscosity $\left(25^{\circ} \mathrm{C}\right)$ & & 10.5 & \\
\hline 4 & Mir & ture properties of cement & $\%$ & 0.2 & \\
\hline \multirow{3}{*}{5} & \multirow{3}{*}{ 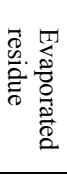 } & Residual content & $\%$ & 60.1 & \\
\hline & & $\begin{array}{l}\text { Needle } \\
\text { penetration }\left(25^{\circ} \mathrm{C}, 100 \mathrm{~g}\right)\end{array}$ & $\begin{array}{l}0.1 \mathrm{~m} \\
\mathrm{~m}\end{array}$ & 80.3 & \\
\hline & & $\begin{array}{l}\text { Solubility(trichloroeth } \\
\text { ylene) }\end{array}$ & $\%$ & $>99.2$ & \\
\hline
\end{tabular}

\begin{tabular}{lllll}
\hline $\begin{array}{l}\text { Serial } \\
\text { numb } \\
\text { er }\end{array}$ & Project & Unit & $\begin{array}{l}\text { Test } \\
\text { results }\end{array}$ & $\begin{array}{l}\text { Test } \\
\text { metho } \\
\mathrm{d}\end{array}$ \\
\hline & ductility $\left(5^{\circ} \mathrm{C}\right)$ & $\mathrm{cm}$ & 29.4 & \\
& ductility $\left(15^{\circ} \mathrm{C}\right)$ & $\mathrm{cm}$ & 85.4 & \\
\hline
\end{tabular}

TABLE6. PROPERTIES OF ANION EMULSIFIED ASPHALT

\begin{tabular}{|c|c|c|c|c|c|}
\hline $\begin{array}{l}\text { Serial } \\
\text { numb } \\
\text { er }\end{array}$ & \multicolumn{2}{|l|}{ Project } & Unit & $\begin{array}{l}\text { Test } \\
\text { results }\end{array}$ & $\begin{array}{l}\text { Test } \\
\text { metho } \\
\text { d }\end{array}$ \\
\hline 1 & \multicolumn{2}{|c|}{$\begin{array}{l}\text { The residues on the } \\
\text { mesh }(1.18 \mathrm{~mm})\end{array}$} & $\%$ & 0 & $\begin{array}{l}\text { JTJ } \\
052-20\end{array}$ \\
\hline 2 & \multicolumn{2}{|c|}{ Polarity of particles } & / & $\begin{array}{l}\text { Negati } \\
\text { ve }\end{array}$ & 00 \\
\hline 3 & \multicolumn{2}{|c|}{ Adaption of cement } & / & Fine & \\
\hline \multirow[t]{6}{*}{4} & \multirow{6}{*}{$\begin{array}{l}\text { Evapora } \\
\text { ted } \\
\text { residue }\end{array}$} & Residual content & $\%$ & 60.4 & \multirow{6}{*}{$\begin{array}{l}\text { JTJ } \\
052-20 \\
00\end{array}$} \\
\hline & & $\begin{array}{l}\begin{array}{l}\text { Needle } \\
\text { penetration }\left(25 \quad{ }^{\circ} \mathrm{C},\right. \\
100 \mathrm{~g}, 5 \mathrm{~s})\end{array}\end{array}$ & $\begin{array}{l}0.1 \mathrm{~m} \\
\mathrm{~m}\end{array}$ & 87 & \\
\hline & & $\begin{array}{l}\text { Softening point(ring } \\
\text { and ball method) }\end{array}$ & ${ }^{\circ} \mathrm{C}$ & 45 & \\
\hline & & $\begin{array}{l}\text { Solubility(trichloroe } \\
\text { thylene) }\end{array}$ & $\%$ & 99.5 & \\
\hline & & $\operatorname{ductility}\left(25^{\circ} \mathrm{C}\right)$ & $\mathrm{cm}$ & 151 & \\
\hline & & $\operatorname{ductility}\left(5^{\circ} \mathrm{C}\right)$ & $\mathrm{cm}$ & 45 & \\
\hline
\end{tabular}

\section{E. Dry material}

To reduce the on-site mixing time, and control the quality of CA mortar, in the process of making slab track CA mortar, we usually mix the cement with expansive agent and sand in advance. That is dry material. On the construction site, we just need to mix the emulsifier asphalt, dry material, polymer and air entraining agent.

\section{THE RESULTS AND DISCUSSION}

\section{A. The cation emulsified asphalt}

When use the cation emulsified asphalt, the values of CA mortar compressive strength effected by different types of the sand are shown in table 7. For the CA mortar that using cation emulsified asphalt, when the types of sand change, the compressive strength has obvious difference. From this table, when use quartz as the raw material of the sand to produce CA mortar, the compressive strength of it has reached highest whose value is $3.695 \mathrm{MPa}$. Although the softening coefficient also reach the highest, the value of which is only 0.677 lower than the level that is required to greater than 0.75 by the less damp or secondary structure[14]. However, when use marble to produce the sand of CA mortar, the compressive strength is quite low, the value of which is only $1.484 \mathrm{MPa}$. The softening coefficient is also very low whose value is only 0.427 . The level of its water resistance is quite low. 
TABLE 7 EFFECTS ON THE COMPRESSIVE STRENGTH OF CA MORTAR INFLUENCED BY THE TYPE OF THE SAND WHEN USE CATION EMULSIFIED ASPHALT

\begin{tabular}{lccr}
\hline $\begin{array}{l}\text { Dry material } \\
\text { type }\end{array}$ & $\begin{array}{l}\text { Compressive } \\
\text { strength before } \\
\text { saturation(MPa) }\end{array}$ & $\begin{array}{l}\text { Compressive } \\
\text { strength after } \\
\text { saturation(MPa) }\end{array}$ & $\begin{array}{l}\text { softening } \\
\text { coefficient } \\
(\%)\end{array}$ \\
\hline marble(positive) & 1.484 & 0.633 & 0.427 \\
calcite(positive) & 3.486 & 2.140 & 0.614 \\
basalt(positive) & 3.100 & 1.893 & 0.611 \\
granite(positive) & 3.441 & 2.170 & 0.631 \\
quartz(positive) & 3.695 & 2.501 & 0.677 \\
\hline
\end{tabular}

Notice: the size of specimen is $\varphi 50 \times 50 \mathrm{~mm}$.

The relationship between the compressive strength ofCA mortar produced by different types of the sand and softening coefficient is shown as figure 1 . The relationship between the two can be described as linear correlation. The higher the compressive strength of $\mathrm{CA}$ mortar is, the higher the value of the softening coefficient will be. Since the sand mainly plays the role of reinforcing particle in CA mortar[15], and the strength of the sand itself is greater than cement or asphalt matrix. So the influence that the sand has on the compressive strength ofCA mortar is mainly related to interfacial bonding strength. The relationship between the compressive strength ofCA mortar and softening coefficient is consistent with this thesis. That is to say, the interface bonding is more closely, the bonding strength is higher, and the interface cannot easily suffer from the water erosion either, the softening coefficient is higher.

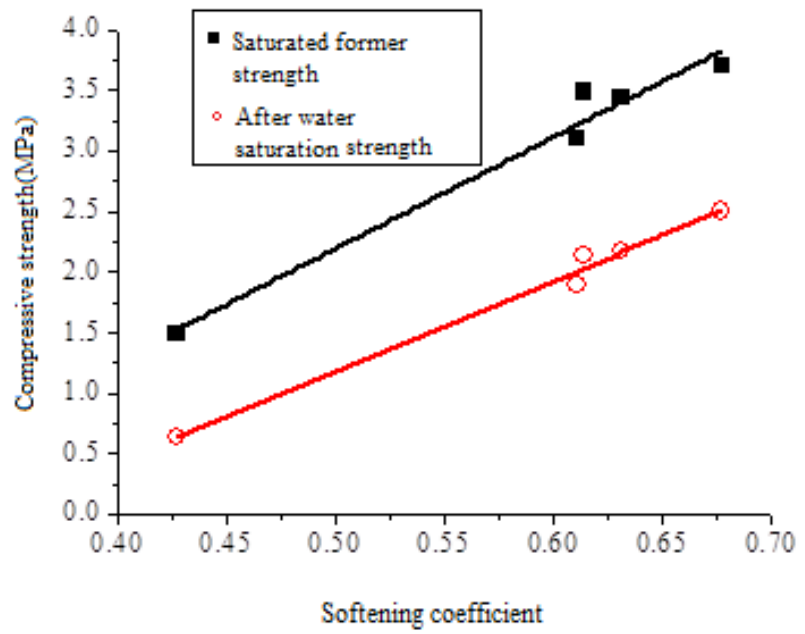

Figure 1 The relationship between the compressive strength of CA mortar and softening coefficient when use cation emulsified asphalt

\section{B. The anion emulsified asphalt}

When use the anion emulsified asphalt, the compressive strength of CA mortar produced by different types of the sand and the softening coefficient are shown as table 8 . The same, the type of sand has notable effects on the compressive strength of CA mortar. From the table, when use calcite as the raw material of the sand to produce CA mortar, the compressive strength of it has reached highest whose value is $3.603 \mathrm{MPa}$. While use basalt as the raw material of the sand to produce CA mortar, the compressive strength has reached lowest whose value is $2.529 \mathrm{MPa}$, the softening coefficient is also the lowest whose value is 0.579 .

TABLE 8 EFFECTS ON THE COMPRESSIVE STRENGTH OF CA MORTAR INFLUENCED BY THE TYPE OF THE SAND WHEN USE ANION EMULSIFIED ASPHALT

\begin{tabular}{llll}
\hline $\begin{array}{l}\text { Dry material } \\
\text { type }\end{array}$ & $\begin{array}{l}\text { Compressive } \\
\text { strength before } \\
\text { saturation } \\
(\mathrm{MPa})\end{array}$ & $\begin{array}{l}\text { Compressive } \\
\text { strength after } \\
\text { saturation } \\
(\mathrm{MPa})\end{array}$ & $\begin{array}{l}\text { softening } \\
\text { coefficient } \\
(\%)\end{array}$ \\
\hline marble(negative) & 2.562 & 1.736 & 0.678 \\
calcite(negative) & 3.603 & 2.238 & 0.621 \\
basalt(negative) & 2.529 & 1.464 & 0.579 \\
granite(negative) & 3.003 & 1.818 & 0.605 \\
quartz(negative) & 3.265 & 2.099 & 0.643 \\
\hline
\end{tabular}

Notice: the size of specimen is $\varphi 50 \times 50 \mathrm{~mm}$.

The relationship between the softening coefficient of CA mortar produced by different types of sand and the strength is shown as figure 1.Different from the CA mortar produced by cation emulsified asphalt, the compressive strength almost has nothing to do with the softening coefficient. Maybe other factors influence the strength of CA mortar. Because of cement hydration, a large quantity of extreme alkalinity $\mathrm{Ca}(\mathrm{OH})_{2}$ has been produced. And formed hydrous $\mathrm{C}-\mathrm{S}-\mathrm{H}$ gelation carries positive charge. For particles of anion emulsified asphalt carry negative charge, compared with cation emulsified asphalt, the type of composite gelation charge formed by the two has changed a lot which means that the two type charge are both carried, while the composite gelation formed by cement hydration and cation emulsified asphalt only carries positive charge.

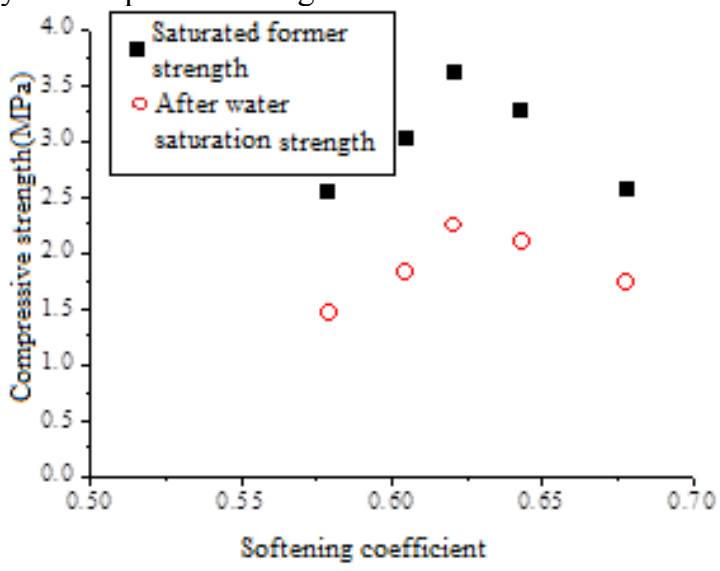

Figure 2 The relationship between the compressive strength of CA mortar and softening coefficient when use anion emulsified asphalt

Put different types of sand into the water, soaking for about 7days, testing the $\mathrm{PH}$ value of soaking fluid, results are shown as table 9. The $\mathrm{PH}$ value of marble is about 10 which also shows stronger alkalinity, while the $\mathrm{PH}$ values of other rocks are only around 8 approaching neutral level. 
Moreover, the compressive strength of CA mortar is sensitive to charge type of emulsified asphalt and the softening coefficient has a great change when use marble as sand. Hence, we can explain 'marble phenomenon' like this: Firstly, marble presents stronger alkalinity, so its particle surface carries positive charge in the water, while cation emulsified asphalt and cement hydration also carry positive charge. The reason of charges repel leads to lower strength and unsatisfied water resistance of CA mortar which produced by cation emulsified asphalt. Meanwhile because anion emulsified asphalt carries negative charge, and electric attraction can make the marble and asphalt particles form better bondability, so that using anion emulsified asphalt to produce the CA mortar can make the compressive strength higher and water resistance better. That the smoother surface of marble might be the reason leading to the lower strength.

TABLE 9 THE PH VALUE OF THE SAND WHICH USED TO PRODUCE CA MORTAR

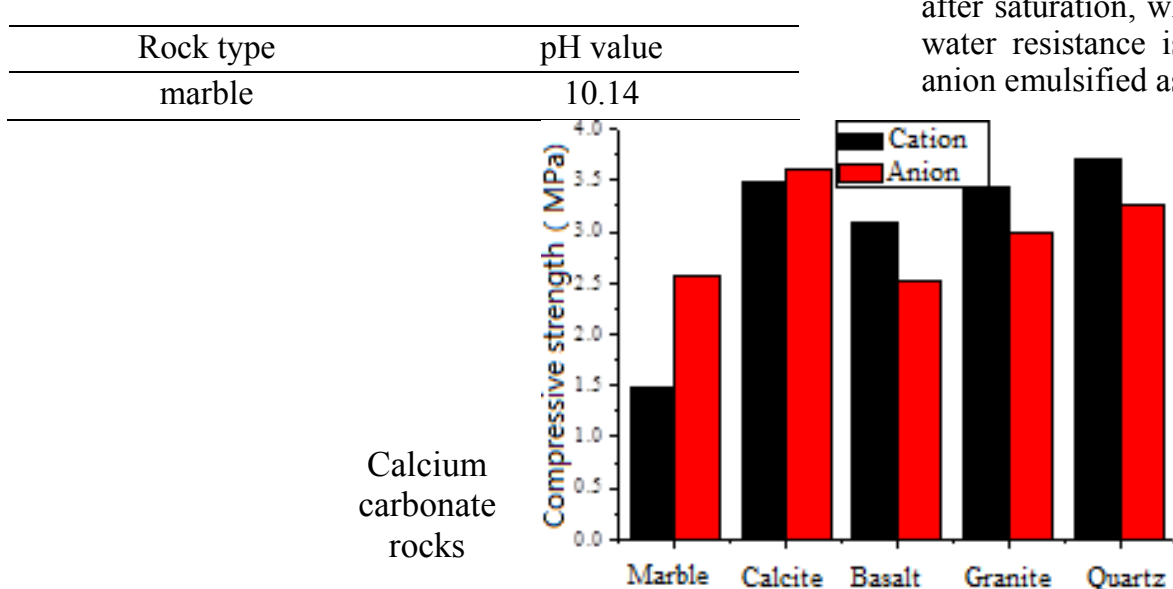

Figure 3 The compressive strength of CA mortar before Saturation

$\begin{array}{cc}\text { calcite } & 8.25 \\ \text { granite } & 8.10 \\ \text { basalt } & 8.32 \\ \text { quartz } & 8.20\end{array}$

\section{Comparison with different emulsified asphalt}

From figure 3 we can see that the effect which emulsified asphalt charge type has on the compressive strength of CA mortar can be divided into two kinds: when marble and calcite use cation emulsified asphalt, the compressive strength is lower than those using anion emulsified asphalt. But for basalt, granite and quartz, the rule has reversed. We can also see the similar rule in water resistance test of CA mortar. As shown in figure 4 and figure 5, when use cation emulsified asphalt, after saturation of the marble and calcite, the decline range of their strength is higher than the condition where use anion emulsified asphalt. While for basalt, granite and quartz, after saturation, when use cation emulsified asphalt, their water resistance is better than the condition where use anion emulsified asphalt.

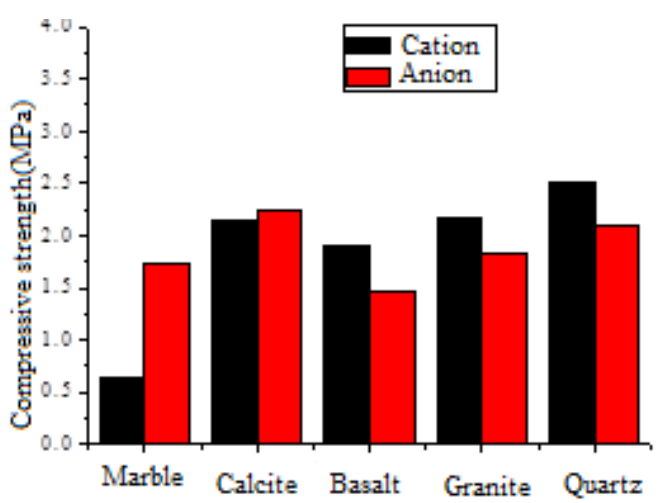

Figure 4 The compressive strength of CA mortar after saturation

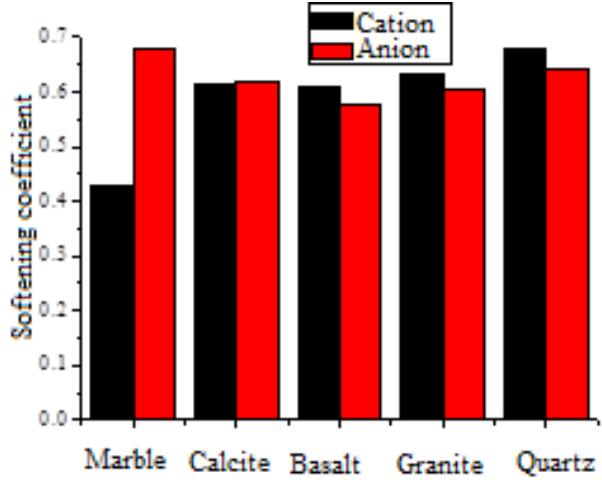

Figure 5 Softening coefficient of CA mortar produced by different emulsified asphalt

The phenomenon said above may be related to chemical compound of sand. The chemical constituents of marble and calcite mainly are $\mathrm{CaCO}_{3}$ which are alkaline aggregate. When put them into water and ionize them, we can see that the surface of them carries positive charge. So 
they can easily absorb asphalt particles which carry negative charge. Which means they can attach well to anion emulsified asphalt. The compressive strength of marble and calcite is higher, and the water erosion resistance ability of them is very well. However, the chemical constituents of basalt, granite and quartz mainly are $\mathrm{SiO}_{2}$ which are acidic aggregate. When put them into water and ionize them, we can see that the surface of them carries negative charge. So they can easily absorb asphalt particles which carry positive charge. Which means they can attach well to cation emulsified asphalt. The same, the compressive strength of them is also higher, and the water erosion resistance ability of them is well too. Different from relative research results about asphalt mixture, when in CA mortar, the charge type of emulsified asphalt has notable effects on the compressive strength and water resistance of CA mortar. The compressive strength of CA mortar produced by alkaline aggregate marble (calcium carbonate) is lower than those produced by acidic aggregate quartz (silica) in the research.

As researched above, when the main chemical constituent of sand is $\mathrm{SiO}_{2}$, it's better to use cation emulsified asphalt so that the compressive strength and water resistance of the CA mortar will be great. While the main chemical constituent of sand is $\mathrm{CaCO}_{3}$, it's better to use anion emulsified asphalt. In general, the quartz composition rocks adapt well for anion or cation emulsified asphalt. Before or after CA mortar saturated, the compressive strength is quite high. And the loss ratio of strength is very low after saturation. Which means asphalt bonding well with the sand interface, and the bonding strength is quite high. So asphalt is an ideal material to produce the sand.

\section{CONCLUSION}

(1) For the calcium carbonate composition rocks like marble and calcite, the compressive strength and water resistance of the CA mortar produced by anion emulsified asphalt are both higher than those produced by cation emulsified asphalt.

(2) For the silica composition rocks like basalt, granite and quartz, the compressive strength and water resistance of the CA mortar produced by cation emulsified asphalt are both higher than those produced by anion emulsified asphalt.

(3) When use marble to produce the sand of CA mortar, whichever the asphalt will be used, all the compressive strength are quite low. This may be related to the strong alkalinity of immersion fluid.

(4) The quartz composition rocks adapt well for anion or cation emulsified asphalt. Because the compressive strength of CA mortar is quite high before or after saturation, so the quartz composition rocks are the ideal material to produce the sand of CA mortar.

\section{ACKNOWLEDGEMENT}

The research has been supported by Natural Science Foundation of China (51208439), Scientific Technology Development Major Program of Railway Ministry (2011G001), Doctoral Scientific Fund Project of the Ministry of Education (20120184120031), Postdoctoral Special Funding Project of China (2013T60859),China Railway Eryuan Scientific Development Project (14126168).

Thanks!

\section{REFERENCES}

[1] COENRAAD E. Recent development in slab track. European Railway Review, 2003, 9 (2):81-85.

[2] SHIGERU M., HIDEYUKI T., MASAO U., et al. The mechanism of railway tracks. Japan Railway and Transportation Review, 1998, 3:38-45.

[3] XIE You-jun, ZENG Xiao-hui, DENG De-hua, et al. Mechanical characteristic of China Railway Track System (CRTS) I type slab tracks CA mortars under different strain rates. Journal of Building Materials, 2010(4): 483-486

[4] XIE You-jun, ZENG Xiao-hui, DENG De-hua, et al. Vibration Adsorption and Separation Capacities of CA Mortar Jour. Journal of Building Materials, 2013(2): 356-360.

[5] JIN Shou-hua, CHEN Xiu-fang, Yang Jun. Key technologies of CA mortar for slab track. China Railway Science, 2006, (3):20-25.

[6] Temporary technology criterion of cement and emulsified asphalt mortar in CRTS (China railway track system) I type slab track of passenger dedicated railway. (in Chinese)

[7] Temporary technology criterion of cement and emulsified asphalt mortar in CRTS (China railway track system) II type slab track of passenger dedicated railway. (in Chinese)

[8] PETERSEN J C, PLANCHER H. Model studies and interpretive review of the competitive adsorption and water displacement of petroleum asphalt chemical functionalities on mineral aggregate surfaces. Petroleum Science and Technology, 1998, 16(1\&2): 89-131

[9] CURTIS C W, JEON Y W, CLAPP D J. Adsorption of asphalt functionalities and oxidized asphalts on aggregate surfaces. Fuel Science and Technology International, 1989, 7(9): 1225-1268.

[10] CURTIS C W, ENSLEY K, EPPS J A. Fundamental properties of bitumen aggregate interactions including adhesion and adsorption. Washington DC: TRB, National Research Council, 2001.

[11] JAHROMI S G. Estimation of resistance to moisture destruction in asphalt mixtures. Construction and Building Materials, 2009, 23: 2324-2331.

[12] HICKAS R G. Moisture damage in asphalt concrete. Washington DC: TRB, National Research Council, 1991

[13] ZENG Xiao-hui, XIE You-jun, DENG De-hua. Temperature effect on early expanding character of cement and emulsified asphalt mortar. Journal of Chinese Ceramic Society, 2012 (2): 33-37.

[14] SHEN Guan-lin, HU Geng-kai. Mechanics of Composite Materials. Qinghua University Press .2006(in Chinese) 